\title{
Significance of Secreted Protein Acidic and Rich in Cysteine Expression in Colorectal Carcinoma
}

\author{
Young Jin Kim \\ Department of Surgery, Clinic of Colorectal Cancer, Chonnam National University Medical School, Gwangju, Korea
}

See Article on Page 93-99

The five hallmark capabilities of cancer cell for invasion and metastasis are self sufficiency in growth signal, insensitivity to growth inhibitory signals, evasion of apoptosis, limitless replicative potential and sustained angiogenesis [1]. There were several consistently appeared metastsasis risk factors of primary tumor with poor prognosis such as poor histologic grade, depth of invasion, and lymphovascular invasion. The stromal compartment is a complex arrangement of stromal cells and extracellular matrix, plus associated growth factors, regulatory molecules, and remodeling enzymes. Blood vessels, nerves, and immune cells are also integral parts of the stroma. These stromal components regulate cell function and maintain overall tissue homeostasis [2]. In cancer, the tumor microenvironment directly influences the growth of the tumor and its ability to progress and metastasis.

Several proteins such as E-cadherin, matrix metalloproteinase were changed during invasion and metastasis. Down regulation of E-cadherin stimulated by many growth factors such as epidermal growth factor receptor, $c-M E T$, fibroblast growth factor receptor, Src-family kinase, insulinlike growth factor-I receptor in tumor cells promote tumor invasion and metastasis.

SPARC is one of the matricellular proteins and has the important role in interaction between the cells and matrix. The apparent contradictory functions of SPARC were reported in angiogenesis, epithelial-to-mesenchymal transition and invasion through matrix metalloproteinase (MMP) according to different sites of cancers .

Expression of SPARC was significantly correlated with the expres-

Correspondence to: Young Jin Kim, M.D.

Department of Surgery, Chonnam National University Hwasun Hospital, Chonnam National University Medical School, 322 Seoyang-ro, Hwasun 519-763, Korea

Tel: +82-61-379-7642, Fax: +82-61-379-7661

E-mail: kimyjin@chonnam.ac.kr

(C) 2013 The Korean Society of Coloproctology

This is an open-access article distributed under the terms of the Creative Commons Attribution NonCommercial License (http://creativecommons.org/licenses/by-nc/3.0) which permits unrestricted noncommercial use, distribution, and reproduction in any medium, provided the original work is properly cited. sion of vascular endothelial growth factor (VEGF) and microvessel density in colon cancer tissues [3]. In ovarian cancer, the absence of SPARC upregulated the expressions of VEGF, VEGFR2, MMP-2, and MMP-9, thereby promoting the angiogenic and metastatic potential of these cancers [4]. SPARC is also able to inhibit VEGF-induced integrin activation and down regulation of MMP-2 and MMP-9.

There were several reports on the role of SPARC as a prognostic factor of colon cancer patients. A survival analysis of colorectal carcinoma patients revealed a poorer prognosis for patients lacking SPARC expression than for patients with normal SPARC expression [5]. Patients with low or absence expressing SPARC had significantly worse overall survival and disease-free survival. The role of SPARC in colorectal cancer cell and stroma as prognostic makers need further study after evaluation of monoclonal antibodies of SPARC because of different results [6].

SPARC has been shown to modulate response to chemotherapy. Addition of exogenous SPARC and/or forced expression of endogenous SPARC improved colon cancer cell response to chemotherapy in vitro [7]. Lower levels of SPARC expression in colorectal cancers may represent a "therapy-resistant" phenotype, and that biologically, low levels of SPARC negatively impacts a tumor's response to chemotherapy [8]. In the future, manipulating host-tumor interactions with the matricellular proteins such as SPARC may be important in preventing carcinogenesis or metastasis, and in treating carcinoma by re-establishing normal control mechanisms [9] or reducing drug resistance.

\section{CONFLICT OF INTEREST}

No potential conflict of interest relevant to this article was reported.

\section{REFERECES}

1. Hanahan D, Weinberg RA. The hallmarks of cancer. Cell 2000; 100:57-70.

2. DeVita VT, Lawrence TS, Rosenberg SA. DeVita, Hellman, and Rosenberg's cancer: principles \& practice of oncology. 8th ed. Philadelphia: Wolters Kluwer/Lippincott Williams \& Wilkins; 


\section{Coloproctology

2008.

3. Liang JF, Wang HK, Xiao H, Li N, Cheng CX, Zhao YZ, et al. Relationship and prognostic significance of SPARC and VEGF protein expression in colon cancer. J Exp Clin Cancer Res 2010; 29:71.

4. Said N, Najwer I, Motamed K. Secreted protein acidic and rich in cysteine (SPARC) inhibits integrin-mediated adhesion and growth factor-dependent survival signaling in ovarian cancer. Am J Pathol 2007;170:1054-63.

5. Yang E, Kang HJ, Koh KH, Rhee H, Kim NK, Kim H. Frequent inactivation of SPARC by promoter hypermethylation in colon cancers. Int J Cancer 2007;121:567-75.
6. Kim JY, Jeong D, Ahn TS, Kim HJ, Park DS, Park SY, et al. Expression of secreted protein acidic and rich in cysteine (SPARC) in the stroma of a colorectal carcinoma is associated with patient prognosis. Ann Coloproctol 2013;29:93-9.

7. Tai IT, Dai M, Owen DA, Chen LB. Genome-wide expression analysis of therapy-resistant tumors reveals SPARC as a novel target for cancer therapy. J Clin Invest 2005;115:1492-502.

8. Tai IT, Tang MJ. SPARC in cancer biology: its role in cancer progression and potential for therapy. Drug Resist Updat 2008;11: 231-46.

9. Joyce JA. Therapeutic targeting of the tumor microenvironment. Cancer Cell 2005;7:513-20. 